\title{
USE OF SMART BOARD IN THE INTEGRATED PROCESS OF (SELF) TRAINING
}

\author{
Laima Railienè \\ Šiauliai University Natural Science Education Research \\ Centre; Kèdainiai 'Rytas' Basic School, Lithuania
}

Rasa Baltušytè

Kèdainiai District 'Šèta' Gymnasium, Lithuania

\begin{abstract}
Annotation
The article provides the advantages and disadvantages of the use of Smart board in the integrated lesson of geography and biology. Some problems are discussed, related with the recent new teaching device at school. The evaluation and possibilities of usage of the Smart board are provided in the article as well as the methodology of the integrated geography and biology lesson in the 11th form. A Smart board is an instrument to make the teaching more interesting, faster and simpler whereas the knowledge of the pupils 'becomes deeper and more generalizing. The basis of this work is curiosity of the pupils, and the help to satisfy this curiosity on the teacher's side. However, it should be mentioned, that the process of preparation for the lesson due to realise the teaching process discussed, is prolonged but this is justified by the increased teaching motivation of the learners. The pedagogical technology includes the sequence of operations, which provides a possibility to achieve high results while using low input; introduces the way of systematic thinking in education, what provides a possibility to thoroughly manage the teaching process.
\end{abstract}

Key words: Smart board, integrated teaching, individualisation and differentiation in the (self)training process, competence of the subject, evaluation and self-evaluation.

\section{Introduction}

The teaching methods and teaching means can vary, however, the most important part of the teaching process is a child, i.e. a pupil. We look for the answer into a question „what?" while talking about the plot and ,how?" while talking about methodology in the teaching process; whereas the most important question appears to be ,why?"; what are the aims so that the teacher has to know so much before coming to a person who is just starting a life way. There is the only answer - to help a child to find himself in the world full of information, to teach him to think independently as well as to make decisions and to trust oneself. At this point a teacher meets a much more difficult task - to prepare a child to orientate oneself efficiently and socially in the world of challenges. Therefore, a question arises - are the means and technologies used properly and efficiently? How the new technologies improve the quality of the training process. How to find the training plot, what methodology and means of teaching to use in order to train a child's critical and creative thinking, how to prepare him to teach all lifelong. The use of information technologies at school provided the teachers new possibilities to interest the pupils in the teaching subject. One of the newest methods which is widely used at schools already, is a Smart Board. 
The progress in material facilities allows new modern technologies as well as a Smart Board to come to the school. Constantly changing information technologies become available for teachers, so the teachers meet a new task - to manage to master the new technologies; moreover, to use them efficiently in the (self) training process. This technology increases the motivation of the learners as well as changes the (self) training process itself, which becomes more effective, enriched with visual and interactive devices. However, despite that the SMART board is easy to use, it meets some problems that could be solved while using innovative solutions (Newton, 2000; Thomas, 2001).

Pedagogical literature provides a term pedagogical technology, which comprises a sequence of operations, provides a possibility to seek high results, while using the least input; moreover, it implements the systematic thinking in the pedagogics, which enables a teacher to manage the training process overall. Pedagogical system is the basis of technological processes. This concept should be understood as interrelated means, methods and process unity, which should be directed into a personality purposefully. It must be noted that the basis of pedagogical technological system consists of purposeful activities in the classroom, at school, in informative activities which comprise all complex interrelated systems. Pedagogical technology is realised with particular technological processes, that is to say, in the process of technologies attention should be paid to a form of teaching of a chosen training topic, directions and means while organising practical activities, consolidating the knowledge and abilities using the newest training methods. Therefore, while performing this concept the attention must be paid into the following components: the form of the lesson organised, didactical attitudes, (self) training styles, the qualification of the teacher. The position of the learners' should be clearly defined by concrete bonds with the other teachers of different subjects in different fields of activities, organising clear structural teaching methods or training ways, using computer and other technological devices. The aim of every teacher to achieve the better (self)training results should motivate to help discuss the essential issue: how to organise the activities so that the best results would be achieved.

The purpose of the analysis: to reveal the possibilities of the usage of Smart Board in the integrated lesson of biology and geography in the 11th form.

\section{The possibilities of the use of Smart Board in the integrated (self) training process of the learners}

The beginning of the use of Smart Board brings much worry into the classroom, disappointment too. Those students of the 11th form who had never seen such a technique, were distracted, were not able to concentrate. Those, who start using the Board, must understand that the beginning of the Smart Board brings some technical difficulties and time-waste is unavoidable. A teacher wastes a lot of time while preparing for the lesson using this technology; moreover, there is very little material in Lithuanian. We met all these inconveniences. Firstly, the class had to be taught the principles of the usage. The students were explained the rules of safe usage of the Board, they were told which side to keep going to the Board so that to prevent the wires. Students memorise the material better not only because that the technology is new and interesting but also the material provided is clear and visual whereas sometimes it is difficult to see what is written on a simple school board. The Smart Board provides a possibility to enlarge the view if it is difficult to see (Betts, 2003).

When the students get used to using the Smart Board, they start using it in other lessons as well. The Board enables students to work on the interactive screen and to save 
the work done. This encourages students to come back, to check the results and comment it. Students are more inclined to analyse their mistakes if they see them on the Smart Board, so you can show the scanned fragments of the most repeated mistakes on the screen and correct together with the students using electronic pencils.

(Self) training with the help of Smart Board differs from the ordinary teaching methods and styles while it has some common points. First of all, any lesson must have a plan, the aims denoted, the presentation of the new material must be related with the familiar knowledge of the students. The stages of the ordinary lesson are the following:

- set of the aims: the aims are formulated, the students are involved at the beginning of the lesson, denoting the points to be learned in the lesson;

- the teaching methods and the teaching aids must meet the goals of the training, the age of the students, their experience and abilities, they should match with the aim and plot of the lesson, choosing proper activities;

- actualisation of the training plot, relating with the experience of the students, their interests, practical needs. Practical use of knowledge, abilities and gained experience in the lesson;

- the informative sources used in the lesson are available for students, they help to gain the necessary skills and competencies effectively.

- a teacher and students summarise together, discuss, evaluate the results of the lesson, students evaluate themselves; a teacher manages to accumulate the information of the evaluation, to notice what and how much students managed to learn.

The use of new technologies in the lessons provides a possibility to develop critical and creative thinking, it evokes initiative, creativity and independency, whereas the main moment of this process is the use of the knowledge and consolidation of the knowledge gained during (self) training process and fulfilling practical tasks (Osborne, Hennessy, 2003; Thomas, 2001). The Smart Board is practicable as it allows the teacher to pay all the attention to the pupil, it also provides a possibility a child to learn actively, promotes the (self) training motivation. Such an activity, the use of informational technologies, in this case a Smart Board, it becomes important:

- a possibility to create a teaching material for a specific lesson;

- to learn the phenomena and the processes in the micro and macro world, to perform an observation of a complex operation with the help of graphics and modelling;

- the software of the Board provides a possibility to organise the process attractively and save the works of the day;

- evokes the energy of the pupils ' activity using different material of the subject;

- to be able to evaluate the reliability of present information as well as the practical value in different aspects, again, using while performing the particular practical tasks;

- $\quad$ provides a possibility to use new products of Microsoft effectively at work.

The structure of the lesson may change when the Smart Board is used. The Smart Board is irreplaceable means when inductive training method is used; so the learners draw conclusion and sort the information gained. The teacher may set the material using different potentiality: to shift an object from one place to another, to work with colourful means thus to interest learners and involve them into activity. Furthermore, learner may work in small groups. At this stage attention may again be drawn to the Smart Board so that the learners share their ideas and discuss further actions in order the learners would work 
purposefully further. A teacher may use all the advantages of the Smart Board so that the learners would be not the passive listeners but would actively work all the lesson time.

The teacher denotes the problem to be solved at the beginning of the lesson, and explains the ways the work is organised in the lesson as well as denotes how the evaluation of the learners will be done. The primary knowledge of the learners is checked by using simple tasks or the whole class discussion. A new topic is explained, and then the learners work in small groups of three or four members and solve the tasks or fulfil other practical tasks (Dabrišiene, 1998). The teacher fulfils the role of a consultant at this time. Further the presentations follow - pupils present their explanation of the task given for the other classmates. It can be a report or a visual presentation with the Smart Board. It is essential to be able to discuss what were the pupils' ideas while listening to the classmates' presentations and what the pupils learned in the lesson. Moreover, to distinguish what was the knowledge before the lesson and what knowledge pupils gained in the lesson. The teacher has to evaluate the work of the learners, and the learners evaluate their personal work in the lesson and their input into the group work (Osborne, Hennessy, 2003).

The teaching material should have such features:

- different perceptive senses should be used (seeing, hearing, touch and other);

- warrant the management of the cognitive activity of the learners;

- provide the training with necessary information;

- to allow the learners to involve into activities;

- to motivate learners to thinking, reasoning, analysis, practise of the knowledge in practical activities more than memorising;

- initiate cooperation of the learners among themselves and with the teacher;

- to promote learners to create personal training products;

- to warrant the reflection of learners training activity.

The integration of the subjects improves the (self) training process, shapes the whole cognizance of the world and consolidates the knowledge of the learners. Pupils fulfil different training activities in the integrated lessons, their need to knowledge is trained (Jackūnas, 1993). Lessons of such type help to practically check the abilities to use the knowledge practically and also it shows what skills must be improved so that the required level of knowledge would be reached. The integration of the subjects allows to choose only the most important information which supplements the common knowledge of some subjects, it also avoids repetition of similar information in separate subjects or presenting apart (Kiliuvienè, 2006; Markauskaite, 2000).

\section{Differentiation and individualisation in the integrated lesson of geography and biol- ogy, using the possibilities of Smart Board}

The choice of the ways of individualisation and differentiation depends on the type of the integrated lesson: whether this is a presentation and explanation of new material, consolidation of the knowledge, generalization or testing of the knowledge, individual or group work of the learners. The individualization and differentiation of (self) training process of the learners is possible during all lesson stages. Moreover, it is possible to manage individualisation and differentiation of (self)training process in different stages of the lesson (Newton, 2000). 
While planning such a lesson and its stages, it is important:

- properly choose and plan the training material;

- the training material should meet the learners abilities;

- to distribute the tasks as quickly as possible;

- learners ability to start work at once and work consistently;

- the teacher's ability to manage to organise work with the whole class and group work, moreover, to manage to eliminate possible problems of the work.

While working in such a style, learners a lot of time work independently. Thus, a teacher introduces the topic of the lesson first and denotes the aims of the lesson, while learners consolidate the gained information producing practical tasks. In other case, a teacher analyses a part of the new material and the learners analyse all the topic. However, a possible style of a lesson is a presentation of a lesson plot and the learners analyse all the material denoted. If individual work is organised with the individualised and differentiated tasks in the lesson, so learners make the tasks individually consulting the teacher. It should me mentioned, the attention must be paid to (self) training individualization, because it provides possibilities to reveal individual potentiality of a learner.

Summing up, planning the training process, it is essential to employ all the possibilities of the Smart Board effectively. It is mostly related to the preparation of practical tasks, keeping in mind individual abilities of the learners. The structure of the integrated lesson is provided in the description and the table.

\section{The plan of the integrated lesson of biology - geography}

1. Topic

2. Aims

To explain the importance of ecosystem variety, the influence on a population changes of biotic and abiotic surrounding.

3. Methods. Problematic conversation, comparison analysis, watching, commentative generalisation of the presentation.

4. Means. Smart Board, presentation „Ecosystem“, encyclopedias: Encarta 2006, Botany Online: The Internet Hypertextbook; lt.wikipedia.org/wiki/Ekosistema.

5. The lesson:

\begin{tabular}{|l|l|l|}
\hline Stages of the lesson & \multicolumn{1}{|c|}{ Teacher's activity } & \multicolumn{1}{c|}{ Learner's activity } \\
\hline & $\begin{array}{l}\text { The topic and the aims are } \\
\text { introduced, it is explained } \\
\text { how the work is organised. }\end{array}$ & $\begin{array}{l}\text { Students help to formulate the aim } \\
\text { of the lesson. }\end{array}$ \\
\hline $\begin{array}{l}\text { Work with the Smart } \\
\text { Board }\end{array}$ & $\begin{array}{l}\text { Demonstration of the pres- } \\
\text { entation }\end{array}$ & $\begin{array}{l}\text { Students get acquainted with the } \\
\text { material, fulfil the table, Ecosystem““ }\end{array}$ \\
\hline $\begin{array}{l}\text { Commentated conver- } \\
\text { sation }\end{array}$ & $\begin{array}{l}\text { The teacher introduces with } \\
\text { the aspects of ecosystem } \\
\text { comparison }\end{array}$ & $\begin{array}{l}\text { Students listen to the information, } \\
\text { write notes, comment the differences }\end{array}$ \\
\hline $\begin{array}{l}\text { Individual work with } \\
\text { Smart Board }\end{array}$ & $\begin{array}{l}\text { The teacher consults asking } \\
\text { questions }\end{array}$ & $\begin{array}{l}\text { Students watch the friends explana- } \\
\text { tion, add comments }\end{array}$ \\
\hline Reflection (5 min.) & Crossword presentation & \\
\hline Evaluation & Formative & \\
\hline
\end{tabular}


While organizing the (self) training process, when geography and biology is integrated into one lesson as well as using the smart board, the desirable teaching result can be reached. In such a way the load of teaching is reduced, the lesson becomes more interesting and more effective. Students train the competencies not only of geography and biology. The common competencies are trained too: cognition, social, ability to learn, communication, initiative, creativity and personal. Moreover, students train naturescience competence in an integrated lesson, where nature-science communication, practical abilities, knowledge and understanding are very important (Kompetencijų ugdymas, 2012).

\section{Summing up}

The integration of the subjects improves the training process, forms wholesome world cognition, consolidates the knowledge of the students. Students make different teaching tasks during the integrated lessons, their need to know more is also trained. Such lessons help to check practically how students are able to use the knowledge gained, what knowledge and skills should be improved so that the desirable skills and knowledge level would be achieved. The Smart Board provides new possibilities in the training process not only to teach new science knowledge but also allows to train a self-efficient and creative personality. The main principle of the lesson organisation is that everybody can work in his own possibilities: speed, preparation and abilities. The work with Smart board helps to integrate subjects expands the variety of didactic methods used in the lesson. A teacher can fulfil a role of a consultant, thus making the teaching process more individual. Students are more inclined to analyse their mistakes if they see them on the Smart Board; therefore the most frequent mistakes can be scanned and shown on the Smart Board so that to check and correct together with the students using the electronic pencils. Especially positive appears to be a reflection, for which different games, crosswords and puzzles are used for generalisation of the topic.

\section{References}

Betts S. (2003). Does the use of ICT affect quality in learning science at Key Stage 3? Studies in Teaching and Learning, 9-17.

Dabrišienè V. (1998). Integruoto ugdymo programu sudarymo principai. Edukologijos studijos Lietuvos mokyklai. Kaunas: Technologija, p. 67-79.

Jackūnas Ž. (1993). Ugdymo integracijos metmenys. Lietuvos švietimo reformos gairès. Vilnius: Valstybinis leidybos centras, p. 89-91.

Kiliuvienė D. (2006). Integruotasis ugdymas. Klaipėda: KU, p. 16.

Kompetencijų ugdymas (2012). Metodine knyga mokytojams. Vilnius, 2012.

Markauskaite L. (2000). Informacijos ir komunikacijos technologijos integravimo ị ugdymą krypčių analizè. Informatika, 2(36), 59-85.

Mokomujų kompiuterinių priemonių naudojimo ir diegimo tyrimas (2003). Vilnius www.smm.lt/svietimo_bukle/docs/MK_tyrimas.pdf

Newton L. (2000). Data-logging in practical science: research and reality. International Journal of Science Education, 22 (12), 1247-1259.

Osborne J., Hennessy S. (2003). Literature review in science education and the role of ICT: promise, problems and future directions. Bristol: NESTA Futurelab. http://www.nestafuturelab.org/research/reviews/se01.htm

School science resource. Available online: http://www.schoolscience.co.uk/

Science and ICT. Available online: http://www.shambles.net/pages/learning/ScienceP/scict/ 
Science. ICT opportunities. Available online: http://www.ncaction.org.uk/subjects/science/ictops.htm

Thomas G. P. ( 2001). Toward effective computer use in high school science education: where to from here? Education and Information Technologies, 6 (1), 29-41.

Science Teaching in Schools in Europe Policies and Research (2006). „Eurydice“ Project Report. Directorate General for Education and Culture, European Commission. Available online: http://www.eurydice.org/portal/page/portal/Eurydice/PubContents?pub=081EN

Received 10 October 2012; accepted 15 November 2012

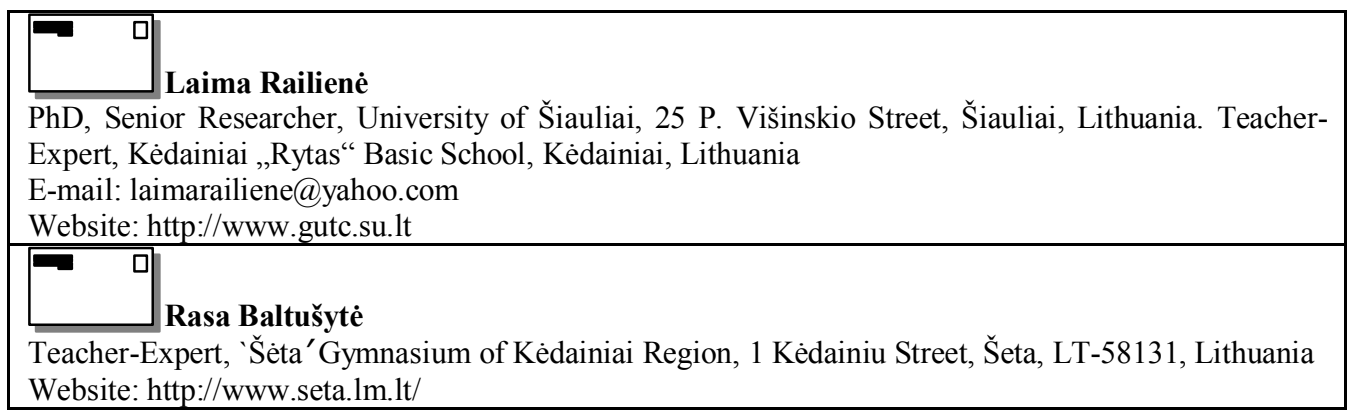

